Editorial

\title{
Politics of COVID-19: Political Epidemiology of and Pandemics
}

Jugal Kishore

Director Professor \& Head, Department Community Medicine, Vardhman Mahavir Medical College \& Safdarjung Hospital, New Delhi.

DOI: https://doi.org/10.24321/2455.7048.202025

I $\quad \begin{array}{lllll}\mathbf{N} & \mathbf{F} & \mathbf{O}\end{array}$

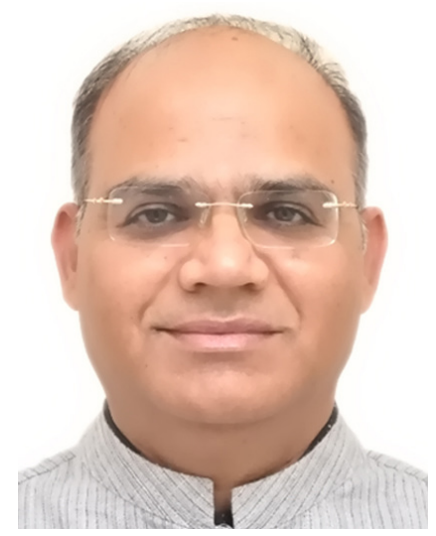

E-mail Id:

drjugalkishore@gmail.com

Orcid Id:

https://orcid.org/0000-0001-6246-5880

How to cite this article:

Kishore J. Politics of COVID-19: Political Epidemiology of Pandemics. Epidem Int 2020; 5(4): 1-4.

\section{$\begin{array}{llllllllllllllll}\mathbf{I} & \mathbf{N} & \mathbf{T} & \mathbf{R} & \mathbf{O} & \mathbf{D} & \mathbf{U} & \mathbf{C} & \mathbf{T} & \mathbf{I} & \mathbf{O} & \mathbf{N}\end{array}$}

"Medicine is a social science, and politics nothing but medicine at a larger scale"

Rudolf Virchow

Rudolf Virchow was convinced that social inequality was a root cause of ill-health, therefore, social science including political power is required to balance such inequality so that diseases can be prevented and controlled. Recent public health successes such as eradication of small pox, rinderpest and elimination of polio and guinea worm infestation, show that adequate political action has often been required before effective public health policies and interventions could be implemented. One of the pillars for success of any policy or, health program is political support and commitment. This is true for disasters including epidemics and pandemics. For their mitigation and preparedne, resource mobilization is one of the vital activities where government plays a crucial role. Many a time government may not be able to provide sufficient resources but channelizing and controlling their use is an important activity which is performed by the government officials.

Epidemics and pandemics have long history of affecting people and their countries. Epidemics have also altered the societies they have spread through, affecting personal relationships, the work of artists and intellectuals. These also affects man-made and natural environments. Scientific development is inevitable requirement during epidemics. It is a survival mechanism of human society. Many innovations take place during epidemics which lead to competition among scientists and their funders. Marketing of innovated products is another area where competition exists. In all of these activities, politics play a crucial role and has a significant impact.

\section{Evidence from History}

If we have a look on the history of epidemics, Bubonic plague killed half the population of world and, therefore, had a tremendous effect on industrial revolution, on slavery and serfdom. Epidemics also, as we are seeing now, have tremendous effects on social and political stability. They have determined the outcomes of wars, and they were likely to be part of the start of wars sometimes due to political instability. All wars, 
epidemics and pandemics have serious adverse impact on the mental health of the people. It is also observed that deviated mental health of the few affects the occurrence of epidemics.

For the occurrence of epidemics and pandemics, sometimes biological agents such as bacteria and viruses are used as weapons to destroy opposition army. During the $6^{\text {th }}$ Century $\mathrm{BC}$, the Assyrians poisoned enemy wells with fungus. During medieval times, it was common for armies to use infected animal carcasses and diseased human corpses to scare and infect opposite armies. Biological agents become the agents of politics.

Wayna Qhapaq (1468-1524) was the third Sapan Inka of the Inca Empire. The Inca empire reached the height of its size and power under his rule, stretching over much of present-day Bolivia, Peru, Argentina, Chile, Ecuador, and southwestern Colombia. But Wayna Qhapaq died in 1524 due a fever likely resulting from the introduction of a European disease - measles or smallpox. The Spaniards had carried a wide variety of deadly diseases to North, Central and South America; and the Native Americans had no acquired-immunity against them. Millions of Central- and South Americans died in that epidemic including Wayna's brother, Auqui Tupac Inca, and Wayna's successor eldest son, Ninan Kuyuchi. ${ }^{1}$

Smallpox killed millions of native inhabitants of Mexico which was introduced by Veracruz with the arrival of Panfilo de Narvaez on 1520 and was credited with the victory of Cortes over the Aztec empire at Tenochtitlan (Present day Mexico City) in 1521.

L'Ouverture was a strong leader, but not stronger than French army. He was able to defeat the French army in Haiti due to yellow fever which occurred simultaneously. By 1801, L'Ouverture was the ruler of Haiti. In 1801, Napoleon sent his brother-in-law, General Victor-Emmanuel LeClerc and 20,000 troops to seize the entire island by defeating L'Ouverture. Yellow fever ravaged Europeans in the New World well before it struck Napoleon's forces in 1802. By the end of April, the disease was destroying the French. LeClerc had lost one-third of his original force to yellow fever, one of the deadliest epidemics the colony had ever known. By June, the French were dying at a rate of 30 to 50 per day. The effect of yellow fever on the French was staggering. Only approximately 3,000 men returned to France. Although estimates vary considerably, as many as 50,000 soldiers, officers, doctors, and sailors may have died from yellow fever. Before reinforcements arrived, LeClerc's original force of 20,000 was reduced to only a few thousand. The slave rebellion succeeded because the slaves from Africa had immunity against plague that white Europeans who were in Napoleon's army didn't have. It led to Haitian independence. ${ }^{2}$
The British were repeatedly stung by the diseases in the Caribbean and South America. In 1741, during an expedition to capture Peru and Mexico, British forces were reduced from 27,000 to 7,000 by a dreaded disease known as "black vomit." Even as late as 1878, a yellow fever epidemic struck more than 100 United States towns, killing at least 20,000 people.

As late as 1710, a Russian army besieged a Swedish City threw plague infected corpse over the city walls. In 1767, during the French and Indian War, the English General, Sir Jeffrey Amherst, gave blankets laced with smallpox to Indians loyal to the French. The epidemic decimated the tribes, arguably, resulting in a successful British attack on Ft. Carillon. This strategy was used to create fear among opposition soldiers. Evidence exists that biological warfare was used against various indigenous Native American tribes in the 1700's. However, deliberate large-scale production and weaponization of biological agents did not start until the $20^{\text {th }}$ century.

During the Sino-Japanese war, the notorious Japanese army experimented with various biological weapons on thousands of human subjects. ${ }^{3}$ Chinese military prisons were deliberately infected with causing diseases such as anthrax, plague, cholera, and as many as eleven Chinese cities were attacked with plague infected fleas.

\section{Conspiracy Theory in COVID- 19 Pandemic}

The current COVID-19 pandemic is also believed to be inflicted against the world economic powers including India. However such claims have been refuted. This conspiracy theory was fuelled due to the existence of a highest-level biocontainment laboratory in Wuhan, the initial epicentre of the pandemic. Initially Chinese authorities didn't allow investigation into the of origin of SARS-CoV-2 in Wuhan which consolidated this conspiracy theory. Another reason for this doubt was the number of COVID-19 cases which were highest in the beginning but started declining and remained lowest since April 2020. This lowest number can't be explained alone due to control measures adopted by Chinese authorities. However, later on the scientific evidence disproved the theory of conspiracy. Although, the threats associated with biological warfare, bioterrorism, and the accidental leakage of deadly viruses from labs are real and growing, such. But, such conspiracy theories damage international peace efforts by creating deep mistrust, animosities, the power of ideologies such as nationalism, and the sacrifice of truth in propaganda campaigns.

\section{Politics in COVID- 19 Pandemic}

During COVID-19 pandemic common people have been shattered due to rising unemployment and high cost of living. The worst situation is internal migration of workers to their home towns from big cities and towns just after 
imposition of lockdown. This brutal preventive method of public health was adopted after the strong-arm method introduced by the Chinese on January 23rd, 2020, when they introduced cordon sanitaire, which is a wholesale quarantine by cordoning off with soldiers and policemen whole geographical areas and communities. In this case, in Wuhan, a city of some eleven million, and then the Hubei Province, which has almost sixty million people, they decided to impose a lockdown. Following this, country after country started imposing lockdown on their people without assessing the whole situation.

That is something which reminded us of the anti-plague measures and that has been repeated over and over, including in the Ebola epidemic. The problem with the cordon sanitaire is that it's awkward. It arrives too late and it breaks down that fundamental element of public health, which is information. That is to say that, threatened with the lockdown, people don't cooperate with authorities. Authorities therefore no longer know what's going on and people take flight, which spreads the epidemic. It differs from the norms of public health, which have developed since the plague years, which stress on case findings of individuals, then tracing and isolation.

The response of the W.H.O., which praised this as a wonderful public health measure is unwelcome. That makes us fearful. The lockdown was tried with Ebola in West Africa, where it didn't work. We should have learnt the lesson. ${ }^{4}$ No lesson learnt from Eloba epidemic. Even the Chinese government accepted their mistake later on about the forceful imposing lockdown. But the mistake kept on repeating itself throughout the world. Why? Was there any politics involved?

\section{Way Forward}

In current era, there is a need to introspect and assess the all the conditions in a comprehensive manner. Managing an epidemic requires tackling the health consequences of the outbreak, as well as its social, political, security, and economic dimensions. This implies setting priorities between various interests and goals in short, a lot of politics.

Many health professionals argue for stricter social countermeasures to keep people at home. To them, saving lives should be the absolute priority and in case of doubts, a 'no-regret' approach should prevail. Many argue that the response should be free from so-called 'political interference'.

However, these measures may also have negative impacts on people's health. It may lead to an increase in domestic violence, rapes, child labour, trigger or worsen mental health issues, or affect the capacity to provide care for other medical conditions. For example, these may can increase inequalities, put people in precarious economic situations, and lead to have many other consequences that cannot be fully anticipated in scientific models.

Politicians need to appear in control of the situation to avoid a panic that could be extremely damaging to society. There is an expectation of clear leadership and authority. The suspension of regular legislative procedures or the declaration of a state of emergency fits this logic.

However, societies are vulnerable in times of crises and politicians also need to respect core societal values, such as democracy for instance. These values are of course specific to different cultures.

How political leadership plays a significant role in decreasing the damage damage by the pandemic is well established. ${ }^{5}$ There are examples of public health successes against COVID-19. Hong Kong, which has a much higher population density than New York City, had fewer than 100 COVIDrelated deaths, in part due to swift and widespread uptake of masking, augmented by easily accessible testing. The US response, however, has been hampered by denial, missteps, delays in scaling up testing, inconsistent messaging, and politicization of public health responses; consequently, community transmission increased in many parts of the United States. National Institutes of health, which is playing a key role in vaccine development, has been have been excluded from decision making processes. Drug Administration is also politicised. ${ }^{6}$ Similar observations were made from India when three National Level public health organizations made a joint statement, stating that the Government did not consult epidemiologists who had better grasp of disease transmission dynamics but consulted modelers to predict the disease burden and plan the action. It also stated that a limited information is available in the public domain, and the government was primarily advised by clinicians and academic epidemiologists with limited field training and skills. Policy makers apparently relied overwhelmingly on general administrative bureaucrats. The engagement with expert technocrats in the areas of epidemiology, public health, preventive medicine and social scientists was limited. ${ }^{7}$

Politics of marketing and supply of testing reagents, machines, ventilators, masks, and sanitizers reminds us of the work of Amartya Sen who wrote that deaths in famines are not due to scarcity of food but due to maldistribution of it. ${ }^{8}$ While the wealth of some has increased manyfold, and others are facing extreme financial crisis. For example, till $7^{\text {th }}$ Nov 2020 there were approximately 320 million COVID-19 tests performed in the world. Out of which 49 million people found positive ( Test positivity 15\%). But only 1.2 million have died, meaning a case fatality rate of $2.4 \%$. Roughly one test costs 100 US dollar means a total of 32,000 million US dollar spent on tests alone. Similarly cost of masks, sanitizers and ventilators ventilators has added to the 
health expenditure. Only big market players have benefited from this whole COVID-19 pandemic. Pharma companies are hoarding for the opportunity to get big business from COVID-19 vaccine. Many companies have already invested billions of dollars in trials and manufacturing of vaccines which is still a distant dream for poor because rich countries have already reserved billions of doses - equal to more than a year's supply - of vaccines for their citizens, leaving little for the world's poor. With such a big business and profit, politics creep in the policy making of investment, manufacturing, and distribution. Pope Francis said that rich countries should not hoard a corona-virus vaccine. He also said it would be a "scandal" if governments doled out pandemic-related bail-out money to only select industries. ${ }^{9}$

We should know that epidemics represent the truth of human behaviour and its outcome. They represent our relationship to our mortality, to our lives. They also reflect our relationships with the environment-particularly the built environment that we create and the natural environment that responds. They show the moral relationships that we have toward each other as people, and we're seeing that today. ${ }^{10}$

We have to think how we have to work together as a human species to be organized to care for one another without considering the boundaries, to realize that the health of the most vulnerable people among us is a determining factor for the health of all of us, and, if we aren't prepared to do that, we'll never, ever be prepared to confront these devastating challenges to our humanity. We need politics for betterment of the humanity but not for selfish gains or inflating ego. we have used politics to make policies and legislation for sustainable environment. In a democratic system change of human behaviour for improvement of conditions and situations is the function of politics and bureaucracy which help technocrats and professionals to achieve the goal of sustainable development.

\section{Conflicts of Interest: None \\ References}

1. McCaa; et al. "Why Blame Smallpox? The Death of the Inca Huayna Capac and the Demographic Destruction of Tawantinsuyu (Ancient Peru). http://users.pop.umn. edu/ rmccaa/aha2004/whypox.htm

2. https://www.montana.edu/historybug/napoleon/ yellow-fever-haiti.html

3. https://fas.org/biosecurity/education/dualuse/FAS_ Introduction/3_A

4. https://www.who.int/news-room/feature-stories/ detail/ebola-then-and-now

5. Dying in a leadership Vacuum (Editorial). N Eng J Med 2020; Oct 8.

6. McGinley L, Abutableb I, Johnson CY. Inside Trump's pressure campaign on federal scientists over a COVID-19 19 treatment. Washington Post. August 30, 2020 (https:// www.washingtonpost.com/health/convulscent-plasmatreatment-covid19-fda/2020/08/29/e39a75ec-e93511ea-bc79-834454439a44_story.html)

7. 2nd Joint Statement on COVID-19 19 Pandemic in IndiaPublic Health Approach for COVID-19 19 Control. Indian J Public Health 2020 Jan; 64 (Supplement): S84-S86.

8. Amartya Sen. Poverty and Famines: An Essay on entitlement and deprivation. Clarendon Press: Oxford 1981.

9. https://www.canberratimes.com.au/story/6886992/ pope-warns-against-vaccine-hoarding/

10. https://newyorker.com/news/q-and-a/howpandemics-change-history. 